\title{
Identidade étnica no Brasil Meridional
}

\author{
Lucy Maffei Hutter ${ }^{1}$
}

ZANINI, Maria Catarina Chitolina. Italianidade no Brasil Meridional: a construção da identidade étnica na região de Santa Maria - RS. Santa Maria (RS): Ed. da UFSM, 2006.

"Italianidade no Brasil Meridional" é um amplo estudo - do ponto de vista antropológico - sobre os descendentes dos italianos de Santa Maria e Silveira Martins, região esta que integrava a extensa área de colonização que se deu no Rio Grande do Sul nos finais do século XIX e princípios do XX.

Dentro dessa visão antropológica a autora considera a italianidade "como uma construção, na qual a veracidade ou autenticidade dos símbolos diacríticos usados para se auto-referirem não é fundamentalmente relevante”. No contexto foi observado como os descendentes dos italianos "apropriam-se de determinados símbolos como seus e lhes atribuem valor e significação”.

A obra - prefaciada por João Baptista Borges Pereira - enfoca o que os descendentes mantêm, ainda, de toda a vivência que herdaram dos italianos, seus antepassados.

Sendo dividida em quatro capítulos, o primeiro analisa como é vista, pelos descendentes dos imigrantes, a travessia do oceano realizada pelos ascendentes que, contada e recontada através das gerações, tornou-se uma referência de valores de personalidade que, em princípio, deveriam ser mantidos ainda hoje. A parte introdutória do capítulo dá uma visão da Itália, então recém-unificada, bem como do Brasil, na época.

A narrativa do imigrante sobre a chegada no Brasil, por vezes meio fantasiada, passada de geração em geração, serve, ainda hoje, como demonstra a autora, para justificar certas ações dos antepassados. Uma descendente explicava a escolha do lote no morro, por parte de seus ascendentes, devido ao medo destes frente ao mar, durante a travessia do oceano. Abrigandose no morro "sabiam que seria quase impossível a água atingir tamanha altura".

Em outro capítulo o enfoque se volta para a proveniência dos imigrantes e o difícil início, adaptação e vivência nos lotes de terra dos núcleos coloniais nos quais acabavam se estabele-

1 Docente / IEB-USP (área de História). 
cendo. Quanto ao trabalho insano até que conseguissem obter recursos da lavoura, passaram os imigrantes, para as gerações que se seguiram, a idéia de que o colono italiano "soffre e lavora con quella tenacitá che é peculiare alla nostra stirpe".

Com relação aos que venceram, a autora destaca a construção do mito do herói, o qual foi, também, passado de geração em geração.

Já aqueles que não conseguiram melhorar a condição econômica eram vistos, entre os conterrâneos, como pessoas com "pouca vontade de trabalhar", como até hoje são designados pelos descendentes.

A religiosidade do italiano - analisada também em outras obras - é relembrada como elemento de importância na adaptação dos peninsulares quando de sua chegada ao Brasil.

No terceiro capítulo a autora analisa a repressão sofrida pelos italianos e descendentes na região de Santa Maria e Silveira Martins, durante a vigência do Estado Novo, que abrangeu, também, a língua por eles falada e as escolas ali mantidas.

A obrigatoriedade do ensino em português fez com que as crianças tivessem de, simultaneamente, aprender as matérias e a língua portuguesa, na época, não dominada por muitos deles.

Aqueles que não falavam o português tornaram-se menos sociáveis temendo a repressão ou, até mesmo, serem considerados traidores da pátria, em se tratando do Brasil.

A repressão deu-se com maior intensidade nos centros urbanos, onde sobreveio tanto o fechamento da Sociedade de Mútuo Socorro, italiana, como saques em estabelecimentos comerciais, quer de peninsulares, quer de alemães.

Na obra em questão é, também, analisada a atuação do jornal local A Razão. Adepto da política nacionalizadora do governo Vargas, considerava mesmo os descendentes de italianos e de alemães membros "perigosos", amigos do Eixo e com possibilidade de atuação favorável ao país de origem.

Com a repressão, os italianos e descendentes foram se adaptando mais aos costumes considerados nacionais. Só voltaram a valorizar a sua origem italiana, e o que herdaram dos hábitos dos antepassados, com a comemoração dos cem anos do início da colonização italiana no Rio Grande do Sul, em 1975.

É dado enfoque à questão da "italianidade" e de que modo, atualmente, os descendentes daqueles provenientes das diferentes regiões da Itália a vêem e/ou a transmitem às outras gerações; e como, com o passar dos anos, costumes brasileiros foram sendo reavaliados e introduzidos entre eles, evidenciando o chimarrão.

A culinária, por sua vez, já se encontra um pouco modificada devido às alterações e adaptações sofridas, no decorrer do tempo. 
Nesse estudo, embora a autora tenha por objetivo analisar "a construção da italianidade entre os descendentes" constata que os mais jovens "descendentes de italianos de Santa Maria e Silveira Martins se sentem, além de brasileiros, gaúchos". Isso não surpreende, visto que os descendentes já se encontram na quinta geração e tendo a facilidade de transporte de um local ao outro, de estudo em outras cidades e, principalmente, com acesso à comunicação de massa, o entrosamento com os nacionais e pessoas de outras origens é muito mais rápido. Assim, os costumes dos antepassados vão ficando cada vez mais distantes no dia a dia do indivíduo, sobrevivendo mais como interesse de dupla cidadania ou mesmo visando a atração turística.

Analisando a zona rural e a urbana, a autora aborda a questão da diferenciação que ainda persiste entre os provenientes de uma e outra região da Itália e mesmo aquela existente entre os descendentes que foram para a zona urbana e lá se estabeleceram e os que continuaram na zona rural.

0 estudo se detém, sobretudo, na busca das origens, por parte dos descendentes dos italianos que se radicaram na região de Santa Maria e Silveira Martins, no Rio Grande do Sul. A história da família é reconstruída e, por vezes, reinventada de acordo com a imaginação de cada membro do núcleo familiar.

Anexos se encontram questionários que serviram de base para as entrevistas realizadas pela autora. Um deles é dirigido aos estudantes do ensino fundamental e médio de Silveira Martins. Neste tem-se a impressão de que a primeira questão é um tanto forçada, premeditando um tipo $\mathrm{X}$ de resposta.

Consta também - além do "Roteiro orientador das entrevistas" - o "Roteiro da pesquisa referente à novela Terra nostra". Neste caso, não se pode esquecer que se trata de uma ficção e, como tal, o autor pode dar asas à imaginação, não tendo o tema, obrigatoriamente, de condizer com a realidade.

A obra em questão Italianidade no Brasil Meridional é, não obstante, um estudo antropológico de peso sobre os descendentes dos italianos na região de Santa Maria e Silveira Martins, no Rio Grande do Sul e, tratando-se de uma excelente contribuição temática merece, sem dúvida, a atenção dos estudiosos da imigração italiana no Brasil. 